\title{
Determination of Dissociation Constant and Stability Constants of Palmitic Acid Complexes with selective Transition Metal Ions in Ethanol- Water Medium By pH-Metric Method
}

\author{
G. Kavitha ${ }^{1}$, P. Vijayarohini ${ }^{2}$, S. Bangaru Sudarsan Alwar ${ }^{3}$ \\ ${ }^{1,2,3}$ Department Of Chemistry,D.G.Vaishnav College, University of Madras, India
}

\begin{abstract}
The stability constants of palmitic acid complexes with $\mathrm{Mn}(\mathrm{II}), \mathrm{Co}(\mathrm{II}), \mathrm{Ni}(\mathrm{II}), \mathrm{Cu}(\mathrm{II})$ and $\mathrm{Zn}(\mathrm{II})$ have been studied using pH measurements in $70 \%(v / v)$ ethanol-30\%(v/v)water medium. The values of proton-ligand stability constant (pK) and metal-ligand stability constant $(\log K)$ of binary complex is calculated using Irving-Rossotti titration technique.
\end{abstract}

Keywords: stability constant, ethanol-water mixture,pHmetric method

\section{Introduction}

Palmitic acid or hexadecanoic acid is one of the mostcommon saturated fatty acid found in animals, plants, and micro organisms.It is a major component of palm oil, palm kernel oil, and coconut oil.It is naturally found inmilk products,meat,cocoa butter, soybean oil and sunflower oil.Palmitic acid is the first fatty acid formed during lipogenesis (fatty acid synthesis) and from which longer fatty acids can be produced. As a result, palmitic acid is a major body component of animals. In humans, one analysis found it to make up 21-30\% (molar) of human adipose tissue [1] and the lipid component of human breast milk[2]. Palmitic acid is used to make soaps, cosmetics, and industrial mold release agents.The aluminium salt of the palmitic acid is used as a solidifying agent of napalm for military purposes[3].In the treatment of schizophrenia, paliperidone palmitate has been synthesized using the fatty palmitate ester as a long-acting release carrier medium when administered intramuscularly.Retinyl palmitate is an antioxidant, a source of vitamin A is included to low-fat milk to compensate the vitamin content lost through the removal of milk fat. Palmitic acid actively increasesmetastasis in mouse models of human oral cancer cells[4].Palmitic acid displays antioxidant properties and helps in the prevention of atherosclerosis in rats.

Recently, a lot of research work is carried outin the study of metal complexes because of their numerous applications in various industries. The metal ions such as cobalt, nickel and copper present in biological fluids are energy sources of life.Thus it is vital to study the stability constants of palmitic acid with various biologically important metal ions.In order to have a quantitative approach extensive research work has been done in the past, in the study of complexes[5].The studies in metal-ligand complexes in a solution of some metal ions with carboxylic acids,oximes,phenols, etc., would be interesting which throw light on the mode of storage and transportof metal ions in abiological system[6]. Narwade et al,have studied metal-ligand stability constants of some lanthanides with some substituted sulphonic acids[7].Shekhon determined proton-ligand stability constants in various aqueous organic mixtures[8].Alot of research was already carried out in this field, but as per the review of the literature[9],it is observed that the information is known about the proton-ligand constant[10] in binary solvent media is very less, and the stability constants of this fatty acid with various metal ions are not available anywhere.

Therefore in the present work,attempts are made to report the interaction and complex formation of selective transition metal ions such as $\mathrm{Mn}$ (II), $\mathrm{Co}(\mathrm{II}), \mathrm{Ni}(\mathrm{II}), \mathrm{Cu}(\mathrm{II})$ and $\mathrm{Zn}(\mathrm{II})$ with palmitic acid in $70 \%(\mathrm{v} / \mathrm{v})$ ethanol- $30 \%(\mathrm{v} / \mathrm{v})$ water medium at $27^{\circ} \mathrm{C}$ and in fixed ionic strength $0.1 \mathrm{M} \mathrm{KNO}$. The ligand is insoluble in water. Hence, $70 \%(\mathrm{v} / \mathrm{v})$ ethanol$30 \%(\mathrm{v} / \mathrm{v})$ water medium was used as a solvent.pH metric method is regarded as tool to the study of solution equilibria because of its precision, dependability,experienced dataanalysis and relatively cheap instrumentation[11].The work is carried out by using Bjerrum $\mathrm{pH}$ metric method as followed by Calvin and Wilson[12]

\section{Materials and Experimental Methods}

All the required chemicals used were of the analar grade.All the solutions were prepared using double distilled water. The stock solution of the ligand was prepared by dissolving required amount of ligand in a minimum volume of ethanol subsequently diluted to final volume. The concentrations of ligand and metal ions are $20 \times 10^{-4} \mathrm{M}$ and $4 \times 10^{-4} \mathrm{M}$ respectively. The ionic strength of the required solutions was maintained at $0.1 \mathrm{M}$ by adding appropriate amounts of $1 \mathrm{M}$ $\mathrm{KNO}_{3}$ solution. The carbonate free sodium hydroxide solution was prepared, and it was standardized using oxalic acid solution[13]. $0.098 \mathrm{M} \mathrm{NaOH}$ solutions was used for performing potentiometric titrations.

\section{Apparatus and Procedure}

All measurements were carried out at $27{ }^{\circ} \mathrm{C}$. Systronics microprocessor based $\mathrm{pH}$ meter (QJ-666B) with a magnetic stirrer and combined glass and calomel electrode assembly used for $\mathrm{pH}$ measurements. This instrument has built in

Volume 6 Issue 12, December 2017 


\section{International Journal of Science and Research (IJSR) \\ ISSN (Online): 2319-7064}

Index Copernicus Value (2016): 79.57 | Impact Factor (2015): 6.391

internal electronic voltage supply with temperature compensator covering the range $0-100^{\circ} \mathrm{C}$. The sensitivity of $\mathrm{pH}$ meter is 0.01 units, the instrument could read $\mathrm{pH}$ range 0.00 to 14.00 in step 0.01 . The $\mathrm{pH}$ meter was switched on half an hour before starting the titration for the initial warm up of the instruments. The $\mathrm{pH}$ meter was calibrated with two buffer solutions of $\mathrm{pH} 7.00$ and 9.20 prepared from a Qualigens buffer tablets.The hydrogen ion concentration was measured with combined glass electrode. Before taking anyreading, the electrodes are washed with distilled water and dried with filter paper.

The following three solutions were titrated separately against standard (carbonate free) $\mathrm{NaOH}$ (total volume $25 \mathrm{ml}$ ) usingCalvin-Bjerrum, and Calvin Wilson $\mathrm{pH}$ titration methods[14].

a) Free $\mathrm{HNO}_{3}\left(2.5 \mathrm{ml}+\mathrm{KNO}_{3} 2.5 \mathrm{ml}\right)$.

b) Solution $\mathrm{A}+$ ligand solution $(5 \mathrm{ml})$

c) Solution $\mathrm{B}+$ metal solution $(1 \mathrm{ml})$.

The $\mathrm{pH}$ readings were taken at fixed intervals and curves of $\mathrm{pH}$ values versus volume of alkali were plotted(Fig.1).The proton-ligand constant was calculated from the $\mathrm{pH}$ values obtained from the titration using the Irving-Rossotti method[15].The metal-ligand stability constants of complexes were also calculated graphically in the binary solvent medium.

\section{Results and Discussion}

The proton ligand constant and metal ligand stability constants of palmitic acid and their complexes with metal ions determined in $70 \%(\mathrm{v} / \mathrm{v})$ ethanol-30\% (v/v) water mixtures at $27 \mathrm{C}$. The proton ligand formation number $\mathrm{n}_{\mathrm{A}}$ was calculated by Irving-Rossotti expression(Table 1).

$$
n_{A}=\frac{\gamma-\left(E^{\circ}+N\right)\left(V_{2}-V_{1}\right)}{\left(V^{\circ}+V_{1}\right) T_{L}^{\circ}} \rightarrow
$$

Where $\gamma$ denotes number of replaceable protons, $\mathrm{N}$ is the concentration of sodium hydroxide $(0.098 \mathrm{M}), \mathrm{T}_{\mathrm{L}}^{\circ}$ is concentration of ligand, $\mathrm{E}^{\circ}$ is the concentration of acid and $\mathrm{V} \circ$ is the initial volume of the reaction mixture. The data of $\mathrm{n}_{\mathrm{A}}$ obtained at various $\mathrm{pH}$ values along the horizontal difference $\left(\mathrm{V}_{2}-\mathrm{V}_{1}\right)$ for representative systems. The dissociation equilibrium can be shown as

$$
\mathrm{HL} \leftrightharpoons \mathrm{H}^{+}+\mathrm{L}^{-} \rightarrow
$$

The $\mathrm{pK}$ values of ligand from the formation numbers were calculated by algebraic method point wise calculations and also estimated by half-integral method, from formation curves $\mathrm{n}_{\mathrm{A}}$ versus $\mathrm{pH}$ (Fig.2) by noted $\mathrm{pH}$ at which $\mathrm{n}_{\mathrm{A}}=$ 0.5 .The accurate value of $\mathrm{pK}$ which is determined by point wise calculations is in good accordance with those achieved by the half-integral method (Table 2).

The increase in $\mathrm{pK}$ in the binary solvent medium than pure water shows that ethanol plays a significant role to enhance the basicity.It is further seen that for a solvent mixture of given composition the $\mathrm{pK}$ value increases as the chain length of the fatty acid increases; this increase in the $\mathrm{pK}$ value may be attributed to the $+\mathrm{I}$ effect and has been found to be more pronounced in the case of an ethanol-water mixture.The study in water-alcoholic mixtures[16] of lower alcoholic content as well as in an aqueous medium is limited by the insolubility of the acids. It is probable that both the specific solvation effect and the bulk solvent structure have a marked influence on the acid dissociation constant.

The metal-ligand stability constants were obtained by the half-integral method by plotting The degree of formation (n) in ligand - metal ions versus $\mathrm{pH}$.The $\mathrm{n}$ values are determined by using the equation

$$
n=\frac{\left(E^{\circ}+N\right)\left(V_{3}-V_{2}\right)}{\left(V^{\circ}+V_{2}\right) T_{m}^{\circ}} \rightarrow
$$

Where $\mathrm{N}, \mathrm{E}^{\circ}, \mathrm{V}^{\circ}$, and $\mathrm{V}_{2}$ have the same significance as in equation (1). $V_{3}$ is the volume of alkali added to obtain the given $\mathrm{pH}$ reading, and $\mathrm{T}_{\mathrm{m}}^{\circ}$ is the concentration of the metal ion in the reaction mixture. The metal-ligand stability constants of various binary complexes have been calculated from n values(fig 3) and are reported (Table 3).

The present work has great importance in the study of the interaction of metal ions with a fatty acid.The deviation of metal titration curves from ligand curve indicate the formation of the binary complex. Since the difference between $\log \mathrm{K}_{1}$ and $\log \mathrm{K}_{2}$ is less,both1:1 and 1:2 complexes are formed simultaneously and not in a stepwise manner.The ligand was found to be a weak complexing agent. The change in color (without precipitation) concerning $\mathrm{pH}$ value of solution and deviation of ligand curve from metal ion curve also shows the commencement of complex formation.

\section{Conclusion}

\section{Proton Ligand stability constant(pK)}

It is observed from titration curve (Fig.1) that the ligand curve starts deviating from free acid $\left(\mathrm{HNO}_{3}\right)$ at $\mathrm{pH}$ greater than2.4.The extent of deviations may be the dissociation of $\mathrm{OH}$ group completely.

\section{Metal-Ligand stability constant $(\log \mathrm{K})$}

The difference between $\log \mathrm{K}_{1}$ and $\log \mathrm{K}_{2}$ values indicates the formation of a complex between metal ion and ligand.The higher value of the ratio of $\left(\log \mathrm{K}_{1} / \log \mathrm{K}_{2}\right)$ for $\mathrm{Co}(\mathrm{II})$ and $\mathrm{Cu}(\mathrm{II})$-ligand complexes indicates the more stable complex formation compared to $\mathrm{Mn}(\mathrm{II}), \mathrm{Ni}(\mathrm{II})$ and $\mathrm{Zn}(\mathrm{II})$-ligand complexes

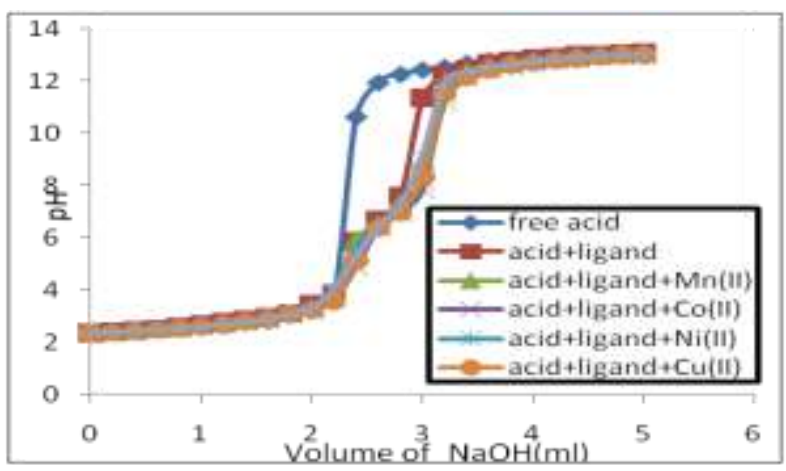

Figure 1: $\mathrm{pH}$-metric curves of free acid +ligand+metalions $\mathrm{Mn}(\mathrm{II}), \mathrm{Co}(\mathrm{II}), \mathrm{Ni}(\mathrm{II}), \mathrm{Cu}(\mathrm{II})$ and $\mathrm{Zn}(\mathrm{II})$ in $70 \%$ (v/v)ethanol$30 \%(\mathrm{v} / \mathrm{v})$ water system

\section{Volume 6 Issue 12, December 2017}


International Journal of Science and Research (IJSR)

ISSN (Online): 2319-7064

Index Copernicus Value (2016): 79.57 | Impact Factor (2015): 6.391

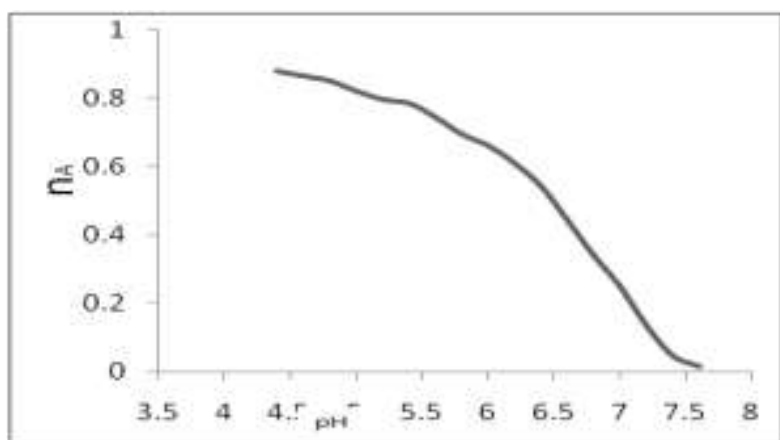

Figure 2: Half integral method for determining $\mathrm{pK}$ of palmitic acid in $70 \%(\mathrm{v} / \mathrm{v})$ ethanol-30\%(v/v)water system

Table 1: Pointwise method for calculation of $\mathrm{pK}$ in 70\%(v/v)ethanol-30\%(v/v)water medium Proton-ligand dissociation constant of palmitic acid at $27^{\circ} \mathrm{Cand}$ ionic strength $\mathrm{I}=0.1$ mol.dm ${ }^{-3} \mathrm{KNO}_{3}$ in $70 \%$ (v/v)ethanol-

\begin{tabular}{|c|c|c|c|c|}
\multicolumn{5}{|c|}{$30 \%(\mathrm{v} / \mathrm{v})$ water medium } \\
\hline $\mathbf{p H}$ & $\mathbf{V}_{\mathbf{1}}$ & $\mathbf{V}_{\mathbf{2}}$ & $\Delta \mathbf{V}=\mathbf{V}_{\mathbf{2}} \mathbf{V}_{\mathbf{1}}$ & $\mathbf{n}_{\mathbf{A}}$ \\
\hline 5.6 & 2.264 & 2.392 & 0.128 & 0.7465 \\
\hline 5.8 & 2.273 & 2.428 & 0.155 & 0.6931 \\
\hline 6.0 & 2.282 & 2.453 & 0.171 & 0.6615 \\
\hline 6.2 & 2.288 & 2.484 & 0.196 & 0.6121 \\
\hline 6.4 & 2.290 & 2.522 & 0.232 & 0.5409 \\
\hline 6.6 & 2.292 & 2.573 & 0.281 & 0.4440 \\
\hline 6.8 & 2.294 & 2.627 & 0.333 & 0.3412 \\
\hline 7.0 & 2.296 & 2.676 & 0.380 & 0.2482 \\
\hline
\end{tabular}

Table 2: $\mathrm{pK}$ values of palmitic acid

\begin{tabular}{|c|c|c|c|}
\hline $\begin{array}{c}\text { Ratio of ethanol- } \\
\text { water mixture }\end{array}$ & $\begin{array}{c}\text { pK(Half } \\
\text { integral } \\
\text { method })\end{array}$ & $\begin{array}{c}\text { pK(pointwise } \\
\text { calculation } \\
\text { method })\end{array}$ & $\begin{array}{c}\text { pK value } \\
\text { in water }\end{array}$ \\
\hline $\begin{array}{c}70 \%(\mathrm{v} / \mathrm{v}) \text { ethanol- } \\
30 \%(\mathrm{v} / \mathrm{v}) w a t e r\end{array}$ & 6.5 & 6.36 & 4.75 \\
\hline
\end{tabular}
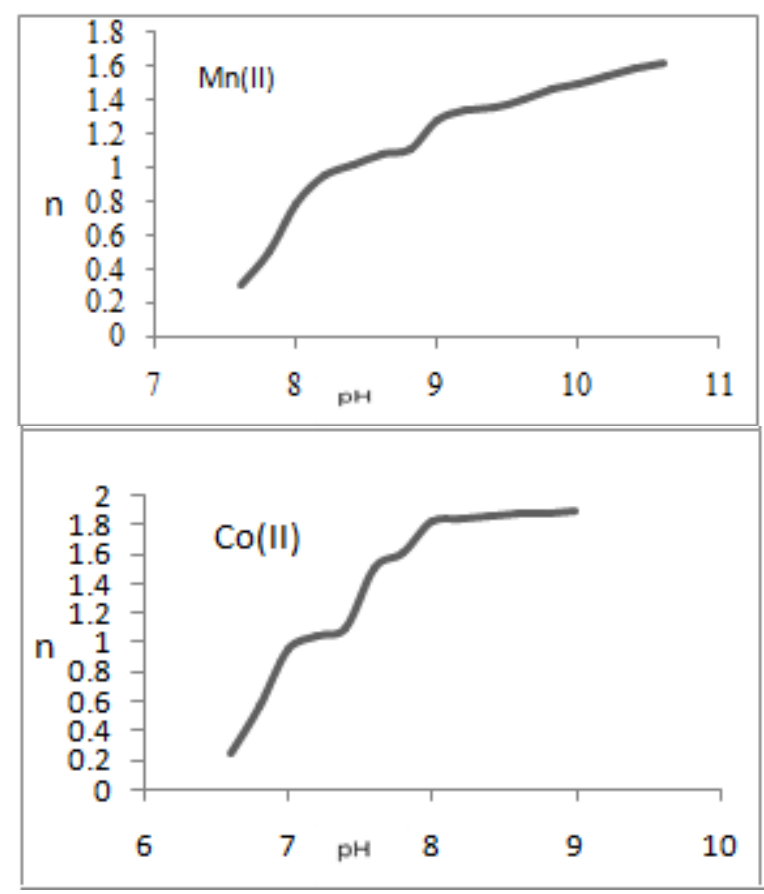

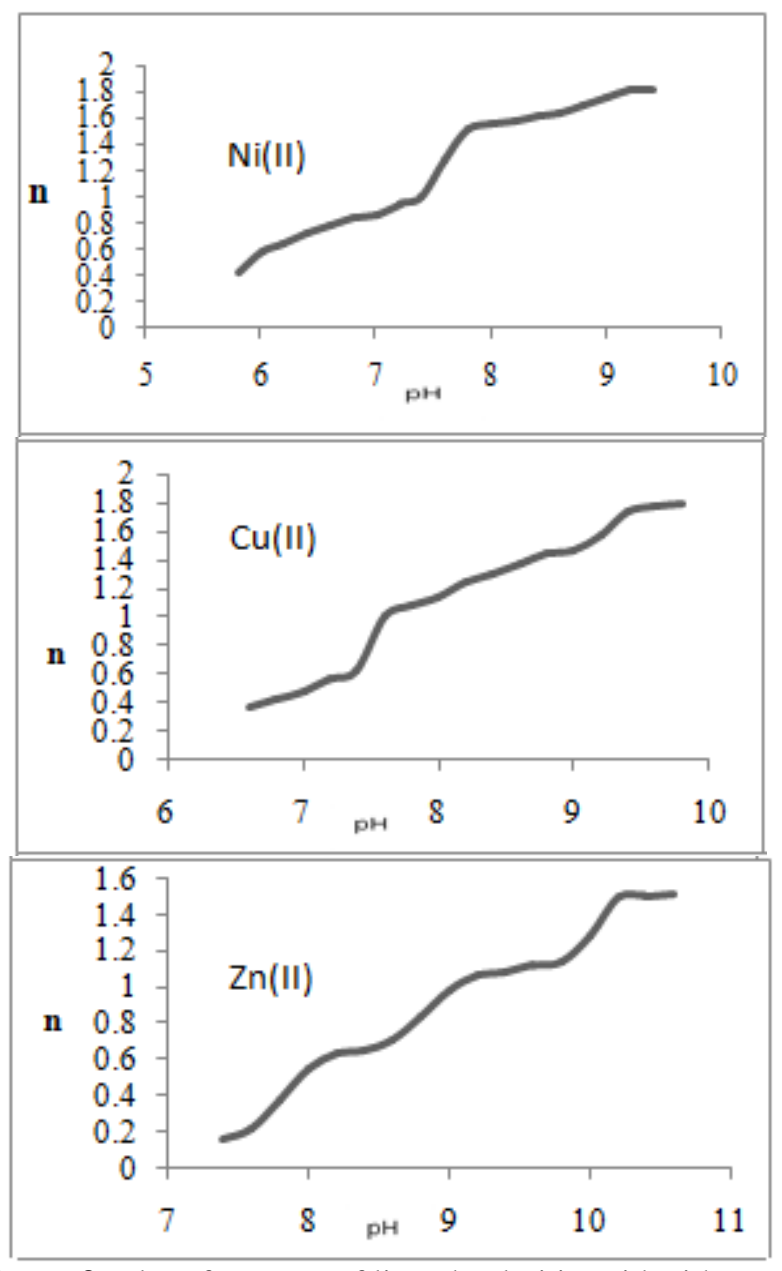

Figure 3: Plot of $\mathrm{n}$ VspH of ligand palmitic acid with metal ions $\mathrm{Mn}(\mathrm{II}), \mathrm{Co}(\mathrm{II}), \mathrm{Ni}(\mathrm{II}), \mathrm{Cu}(\mathrm{II})$ and $\mathrm{Zn}(\mathrm{II}) 70 \%(\mathrm{v} / \mathrm{v})$ ethanol$30 \%(\mathrm{v} / \mathrm{v})$ water medium.

Table 3: Metal -ligand stability constants palmitic acid with transition metal ions in $70 \%(\mathrm{v} / \mathrm{v})$ ethanol-30\%(v/v) water medium

\begin{tabular}{|c|c|c|c|c|}
\hline System & $\log \mathrm{K}_{1}$ & $\log \mathrm{K}_{2}$ & $\begin{array}{c}\log \mathrm{K}_{1^{-}} \\
\log \mathrm{K}_{2}\end{array}$ & $\begin{array}{c}\log \mathrm{K}_{1} / \log \\
\mathrm{K}_{2}\end{array}$ \\
\hline $\mathrm{Mn}$ (II) - L & 3.097 & 2.429 & 0.667 & 1.275 \\
\hline $\mathrm{Co}$ (II) - L & 3.067 & 2.599 & 0.467 & 1.179 \\
\hline $\mathrm{Ni}$ (II) - L & 2.997 & 2.599 & 0.397 & 1.153 \\
\hline $\mathrm{Cu}$ (II) - L & 2.947 & 2.489 & 0.457 & 1.184 \\
\hline $\mathrm{Zn}$ (II) - L & 3.037 & 2.519 & 0.517 & 1.205 \\
\hline
\end{tabular}

\section{References}

[1] Kingsbury K. J, Paul S,Crossley A, Morgan D. M,The fatty acid composition of human depot fat,1961,78: 541-550.

[2] Jensen RG,Hagerty MM, McMahonKE ,Lipids of human milk and infant formulas: a review,Am. J. Clin. Nutr.,1978,31: 990-1016.

[3] Robert M. Neer,Books in brief. Napalm: An American Biography Harvard University Press,29.2013.352-496.

[4] Pascual, Gloria etal.,Targeting metastasis-initiating cells through the fatty acid receptorCD36,2016.

[5] A.E.Martell and M.Calvin,Chemistry of metal chelate compounds, 1962

[6] F.H.C.Rossetti and H.Rossotti,The determination of stability constants, McGraw Hill Book Co.

\section{Volume 6 Issue 12, December 2017}

www.ijsr.net

Licensed Under Creative Commons Attribution CC BY 


\section{International Journal of Science and Research (IJSR) \\ ISSN (Online): 2319-7064}

Index Copernicus Value (2016): 79.57 | Impact Factor (2015): 6.391

[7] M.L.Narwade,M.M.Chincholkar,S.W.Sathe,J Indian Chem Soc, 1985,62,194

[8] B S Sekhon, JuhiSrivastava, S Kaur,Indian J Chem., 2008,85:1082

[9] Harminder Kaur, AnitaSingla,International Journal of Pure \&Applied Chemistry,2011,6:149-153.

[10] D.T.Tayade,A.B.Wadekar,International Journal of Applied Research,2015,01:640-642

[11] Hussain et al.,Chemistry Journal,2012,02:.206-209

[12] AbdalazeemA.Omar,ElmugdadA.Ali,International Journal Of Advanced Chemistry,2015,03:pp 6-13

[13]P.Vijayarohini et al.,International Journal of Science and Research,2015,ISSN(online):2319-7064.

[14] AvinashRamteke,MarutilNarwade,Archives of Applied Science Research,2013,5:231-237.

[15] Muhammad A.Rahman, AshimK.Ghosh and Rathindra N. Bose,Chem.Tech.Biotechnol,1979,29:158-162

[16] Irving H M,Rossetti H S.J.Chem.Soc., 1954,2904.

[17] BertoS,DianelePG,LandoG,PrenestiE and SammartanoS, Int.J.Electrochem.Sci.,2012;7: 10976.

[18] A.I.Vogel,A Text Book of Quantitative Inorganic Analysis, $4^{\text {th }}$ ed;Longman;London 1978

[19]Bjerrum J.Metal Ammine Formation in aqueous solution, 1941.

[20] Calvin M,Wilson K W,J .Am Chem.Soc.,1945,67:2003

[21] Cataldo S, Gianguzza A, Pettingano A, Piazzesse D and Sammartano S, Int.J.Electrochem.Sci.,2012,7: 6722.

Volume 6 Issue 12, December 2017

www.ijsr.net

Licensed Under Creative Commons Attribution CC BY 